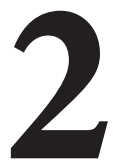

\title{
ANALYSIS OF THE PSYCHOSOCIAL PROFILE OF PRE-SERVICE TEACHERS
}

\section{(ANÁLISIS DEL PERFIL PSICOSOCIAL DE LOS FUTUROS DOCENTES)}

Inmaculada García-Martínez

University of Granada, Spain

José María Augusto-Landa

Eufrasio Pérez-Navío

Samuel P. León

University of Jaén, Spain

DOI: 10.5944/educXX1.30236

\section{How to reference this article/Cómo referenciar este artículo:}

García-Martínez, I., Augusto-Landa, J.M., Pérez-Navío, E., \& León, S.P. (2022). Analysis of the psychosocial profile of pre-service teachers. Educación XX1, 25(1), 41-65. https://doi.org/10.5944/ educXX1.30236

García-Martínez, I., Augusto-Landa, J.M., Pérez-Navío, E. y León, S.P. (2022). Análisis del perfil psicosocial de los futuros docentes. Educación XX1, 25(1), 41-65. https://doi.org/10.5944/ educXX1.30236

\section{ABSTRACT}

University students face many challenges that affect their mental health during this stage. Psychosocial aspects, such as resilience, help to address the imbalance they often experience in their daily lives. The aim is to find the relationship between students' resilience and their mental health, while analyzing the mediating role played by personality factors between these variables. To carry out this study, a sample of 692 university students belonging to different Degrees of Education answered three questionnaires voluntarily, one to measure resilience (RS-14), another to measure personality factors (Big Five) and another to measure mental health (MH-5). A mediational model based on Structural Equations was proposed for this analysis. The results indicate that resilience is able to 
significantly predict students' mental health directly and that it also predicts all personality components assessed in students. Furthermore, it was found that of all the personality factors examined, only neuroticism was found to be predictive of mental health. Furthermore, resilience is positioned as a mediating factor between mental health and personality factors. Specifically, resilience emerged as a significant mediator in the relationship between agreeableness, neuroticism and openness and mental health. Moreover, all other personality factors are directly related to resilience. In the same way, the results also confirm the need to train pre-service teachers in psychosocial factors in order to prevent future problems in their subsequent professional performance.

\section{KEYWORDS}

Resilience, mental health, personality, preservice teachers, structural equation models

\section{RESUMEN}

Los estudiantes universitarios se enfrentan a muchos retos que afectan a su salud mental durante este periodo. Los aspectos psicosociales, como la resiliencia, ayudan a corregir el desequilibrio que suelen experimentar en su vida diaria. El objetivo es conocer la relación entre la resiliencia de los estudiantes y su salud mental, analizando al mismo tiempo el papel mediador que juegan los factores de personalidad entre estas variables. Para llevar a cabo este estudio, una muestra de 692 universitarios pertenecientes a diferentes Grados de Educación respondieron voluntariamente a tres cuestionarios, uno para medir la resiliencia (RS-14), otro para medir los factores de personalidad (Big Five), y otro para medir la salud mental (MH5). Para realizar este análisis se propuso un modelo mediacional basado en Ecuaciones Estructurales. Los resultados indican que la resiliencia es capaz de predecir significativamente la salud mental de los estudiantes de forma directa y que también predice todos los componentes de personalidad evaluados en los estudiantes. Asimismo, se encontró que, de todos los factores de personalidad examinados, sólo el neuroticismo demostró predecir la salud mental. Asimismo, la resiliencia se posiciona como un factor mediador entre la salud mental y los factores de personalidad. Concretamente, surgió ser un mediador significativo en la relación de amabilidad, neurotismo y apertura y salud mental. Además, el resto de los factores de personalidad se relacionan directamente con la resiliencia. Asimismo, los resultados confirman la necesidad de formar a los profesores en prácticas en aspectos 
psicosociales para prevenir futuros problemas en su posterior desempeño profesional.

\section{PALABRAS CLAVE}

Resiliencia, salud mental, personalidad, profesores en formación; modelos de ecuaciones estructurales

\section{INTRODUCTION}

Higher education students should be the main beneficiaries of health prevention (Conley et al., 2015). There is extensive evidence of many mental health problems in this group. Depression, anxiety, high stress or general psychological distress are the most common problems in this type of population (Liu \& Yan, 2020; Schad \& Johnson, 2019). These problems are associated with negative outcomes such as poor academic performance and school dropout. Several studies have noted these problems (Bore et al., 2016); thus, Steptoe et al., (2007) studied depressive symptomatology in university students from 23 countries, finding severe depressive symptomatology in $38 \%$ of university students from East Asia (Japan, Korea). A current study conducted with Spanish university students (Ballester et al., 2020) has shown that first-year university students tend to suffer from mental disorders, with depression and anxiety as the most frequent ones. Mental health problems among college students have negative impacts on academic performance and social function. In the same direction, a meta-analysis conducted by Richardson et al., (2012) examined the relationship between mental health and academic performance, finding that overall, stress has a direct impact on academic performance. Auerbach et al., (2016), using surveys, studied health problems in college students in several countries around the world, and their results showed that college students with psychiatric problems were reluctant to attend college and refused treatment. Irie et al (2019) conducted a recent meta-analysis and their results indicate that cognitivebehavioral variables generally correlate with mental health status. Thus, according to the authors, psychological treatment, including the thinking process, can be effective in the treatment of negative mental health issues.

There are a number of strengths such as adaptive social and emotional skills, self-perceptions and supportive interpersonal skills that can protect students from the negative effects of emotional distress (Ramón-Arbués et al., 2020). Therefore, self-perceptions (e.g., self-esteem), social and emotional skills (e.g., adaptive coping) and interpersonal relationships (e.g., 
social support) have been found to predict social and academic success in higher education.

These findings are particularly important in the analysis of mental health in pre-service teachers because their future professional performance is linked to academic and emotional situations that may affect their mental health (Alonso-Fernández, 2014). The management of working time or relationships with students and families are some of the situations considered as part of occupational health in the educational field (Carmel \& Badash, 2019).

Part of the research on mental health in teachers has been aimed at identifying the impact that psychosocial factors, notably stress, have on mental health (Alonso-Fernández, 2014). Another line of research analyzes the relationships between these situations and teaching performance (Shackleton et al., 2019). A third line of research is interested in offering responses to this situation through proposals that include different general dimensions such as improving working conditions, research and training programs (Anderson et al., 2019).

\section{RESILIENCE}

Generally speaking, resilience refers to the resources and skills that a person needs to address complex situations (Li \& Hasson, 2020). In this regard, resilience refers to an individual's ability to maintain health and psychological well-being despite experiencing adversity. As Leon \& Halbesleben (2014) point out, resilience increases psychological wellbeing and enables individuals to remain self-confident and psychologically positive and healthy in the face of significant challenges and adversity. Studies have shown that resilience is related to physical and mental health and job satisfaction.

Related to the teaching profession, a set of constructs that make up personality and psychosocial factors have been identified as predictors in the analysis of effective teachers. The rationale of teaching as an essentially social profession provides enough arguments to point to the critical role of training in psychosocial skills, such as resilience or emotional intelligence, to ensure the success of pre-service teachers when they enter the world of work (Sautelle et al., 2015).

Recent studies on the value of resilience for the regulation of teachers' mental health incide, on the one hand, on the importance of resilience skills in emotionally healthy professional practice (Aguaded \& Almeida, 2016); 
and, secondly, on the need to include the development of resilience skills in the training of pre-service teachers (Mérida-López et al., 2020).

This research highlights the diversity of areas in which we are currently trying to understand and respond to the mental health of teachers. However, many of these proposals are developed with in-service teachers. From this approach, the intervention is carried out as a reaction against a need that, although known and expected, is addressed once it manifests itself, i.e. during the years of teaching practice. While this reactionary perspective may be useful in other situations, it is insufficient when it concerns psychosocial factors. Indeed, research draws attention to the need of developing emotional skills as a way to cope with everyday situations and to foster resilient attitudes in teachers. In this regard, studies have analyzed the relationship between university education and the impact of the work context on first-year teachers, and they found that teachers who were more likely to be stressed showed higher levels of burnout and less control in the classroom (Fitchett et al., 2018).

\section{PERSONALITY TRAITS}

Taking as reference the model proposed by the Big Five theory (FFM; Digman, 1990), there is a description of the structure of individual personality differences. The Five Factors Theory (FFT; Costa \& McCrae, 1985; McCrae \& Costa, 2008) was designed to explain individual development and functioning in light of research findings from the FFM. The FFM has become the most widely used and empirically supported personality model as a "universal" model of personality, as it is replicated across gender, language and culture (McCrae \& Costa, 2008; John et al., 2008).

It consists of five broad dimensions of personality traits. These traits represent stable individual differences in the thoughts people have, the feelings they experience and their behaviors. Thus, personality would be composed by Extraversion, Agreeableness, Conscientiousness, Neuroticism and Openness to experience, from whose conjugation it is determined how a person is (Benet-Martinez \& John, 1998; Costa \& McCrae, 1985; 1992; Digman, 1990). As John and Srivastava (1999) point out, this taxonomy can reflect the different systems of personality description in one common framework, thus playing an integrative role. Neuroticism is the tendency to experience negative emotions (e.g., sadness, anxiety and anger) and to experience negative thoughts (e.g., worry, self-doubt). This trait represents the predisposition to experience psychological distress. It has been related to the negative affectivity/negative emotionality dimension from other trait models (Digman, 1990; John, et al., 2008; McCrae \& Costa, 2008). In 
contrast, extraversion is the tendency to be sociable, energetic, assertive, animated and experience positive emotions (e.g., happiness) and having positive thoughts (e.g., optimism). It has been related to the positive affectivity component from other trait models. Although neuroticism and extraversion were originally thought to be closely related, they are actually quite independent of each other (Digman, 1990; John et al., 2008; McCrae \& Costa, 2008).

Openness to experience consists of intellectual curiosity, creativity, esthetic sensitivity and non-dogmatic attitudes. Openness to experience makes a distinction between openness to new experiences and conventionality. People who are open to new experiences are open-minded to new ideas and approaches (Costa \& McCrae, 1985). They are curious, creative, insightful, original and imaginative. Openness to experience is associated with intellectual curiosity, experiencing new ideas, esthetic sensitivity and broad interests, and unusual thought processes (Costa \& McCrae, 1992).

Agreeableness can be defined as one getting along well with others. It includes prosocial, altruistic, trusting, warm and understanding (Digman, 1990; John et al. 2008; McCrae \& Costa, 2008). Finally, conscientiousness includes being responsible, reliable, disciplined and organized. Furthermore, it represents a disciplined effort to achieve goals and strong adherence to principles (John et al., 2008). This dimension makes a distinction between being conscientious and careless. Conscientious individuals have a high level of organization, persistence and motivation for goal-directed behavior and may delay gratification. They are prompt, hard-working, confident, responsible, efficient and not indifferent. Conscientiousness is associated with self-discipline, productivity, ethical behavior, high level of aspiration and achievement striving.

Also, personality is more strongly related to the affective component of emotional well-being than to its cognitive component. Studies suggest that personality is an important predictor of individuals' well-being because it is related to how people react to stimuli and events in different life contexts (Gong et al., 2020). According to Lyubomirsky et al. (2005), two traits have been most closely related to well-being: extraversion, which is associated with emotions and positive affect, and as a result, provides high scores in subjective well-being. On the other hand, emotional stability plays a significant role in regulating the response to events and emotional reactions which are responsible for well-being.

Specifically to the university environment, some studies undertake resilience training from a cognitive approach to encourage the comprehensive 
development of students through a personality model based on intra- and interpersonal resilient resources in university classrooms (Belykh, 2018). Some studies point out that resilience may vary if the circumstances change. In that sense, we could not affirm that resilience is an entirely stable characteristic in a person but, still, resilience could be enhanced through training and development activities (Robertson et al., 2018). Despite such evidence, there is also scientific support for the idea that personality factors are related to resilience. In this way, studies have shown that neuroticism relates in a negative way with resilience while extraversion does so in a positive way.

In the previous literature search, a gap has been found regarding studies which examine these three variables in combination with university students and, specifically, those belonging to education degrees. In order to address this, this paper has been developed to unify these factors in future teachers. Thereby, the aim of this research is to test the mediating role of pre-service teachers' resilience with respect to their mental health and personality factors, through structural equation modeling. Moreover, the validity and internal consistency of the instruments used in this study will be analyzed.

\section{METHOD}

\section{Participants}

The sample is made up of a total of 692 university students of Preschool and Primary Education degrees and the Master's Degree in Teaching at Andalusian universities (Spain). In relation to gender, it was found that $73.26 \%$ were women and $26.74 \%$ were men. In relation to age, participants were between 19 and 39 years old and the average was 21.41 years. With regard to qualifications, 47\% were enrolled in Primary Education degree, 25\% in Pre-school Education, 10\% in Social Education, 4\% in Logopedics, another $10 \%$ were studying for a Master's Degree in Teaching and the remaining $4 \%$ were studying for other degrees. This latter range includes all those who were studying a degree whose frequency with respect to the total is less than $1 \%$. Regarding the course, it was found that $57 \%$ were enrolled in the first year, $12 \%$ in the second, $17 \%$ in the third and $14 \%$ in the fourth. Finally, with regard to the province, it was found that $60 \%$ were studying in Jaén, followed by Granada (13\%), Córdoba (12\%), Cádiz, Málaga and Seville (all with 3\%), and 5\% belonged to other provinces, whose frequency with regard to the total is less than $1 \%$. 
The sampling method was intentional, asking for voluntary participation of university students through telematic methods. Previously, the minimal sample size was calculated at $95 \%$ confidence level, with a $5 \%$ confidence interval at $80 \%$ of statistical power. The estimated minimum sample size was 385. According to Hair et al. (2010), the general rule to calculate the minimum sample size for factor treatment in a survey is to have a minimum of 5 observations per variable (5:1). In the current study, the scales consisted of 63 items, so the minimum for the factorial treatment would be 315 .

\section{INSTRUMENTS}

Three scales were administered for the present study. First, the Spanish adaptation of Big five by Benet-Martinez and Johnson (1998) was used to measure personality, with 44 items. This scale is composed of 5 dimensions, being: (a) Extraversion, (b) Agreeableness, (c) Conscientiousness, (d) Neuroticism and (e) Openness. The Big five personality scale has obtained good levels of reliability according to the authors Benet-Martínez and Johnson (1998) with Spanish population, as Extraversion (.85); Agreeableness (.66); Conscientiousness (.77); Neuroticism (.80) and Openess (.79). The overall mean reliability of the scale was .78.

Secondly, the RS-14 scale validated by Sánchez-Teruel and RoblesBello (2014) was used to determine resilience, which consists of 14 items, distributed in two dimensions: (a) Personal competence and (b) Selfacceptance and life acceptance. As for the RS-14 Resilience Scale, it showed a good level of reliability reported by the authors Sánchez-Teruel and Robles of .79. Finally, the Mental Health Inventory-5 (MH-5), which is a 5-item scale and measures current perceptions of mental health, was administered. The MH-5 has similar reliability and validity statistics as the full 38-item MH. Specifically, studies such as the one by Alonso et al. (1995) report a Cronbach alpha of .79.

\section{PROCEDURE}

The questionnaire was administered using Google Form. Our instrument was finally composed of 3 scales, giving a total of 63 items. The final version of the questionnaire began with a section detailing the objectives of the study and a checkbox for voluntary acceptance to participate in the study. Each one of the scales was presented in different blocks, the first one being Resilience, made up of 14 items, using a Likert scale with 7 answer options, in which 1 is "Completely Disagree" and 7 is "Completely Agree", followed by Personality, consisting of 44 items, with 5 answer options, 
where 1 is "Completely Disagree" and 5 is "Completely Agree" and, finally, Mental Health, consisting of 5 items with a Likert scale of 5 answer options, where 1 is "Never" and 5 is "Always".

Regarding the procedure followed in the administration of the questionnaires, the researchers attended the classes of the potential participants to explain the purpose of the study and the procedure for filling in the questionnaires. In those cases where it was not possible to attend the classes, teachers were informed by researchers so they could report all the information to their students and provide them with the link for the fulfillment of the questionnaire. Students accessed the online questionnaire with their digital devices (mobile phone, tablet or laptop) through the link mentioned above provided by the researchers via the virtual teaching platform. It is worth mentioning that in all cases, the emails of the researchers were provided so that they could contact them in case of doubts or for further information. Participation in the study was entirely voluntary, in accordance with the requirements of the Declaration of Helsinki. This research has been approved by the Ethics Committee of University of Jaén (Reference: OCT.20/1.TES).

\section{DATA ANALYSIS}

All analysis in this study was conducted with $\mathrm{R}$ software. The statistical significance criteria for all the tests performed in the study were set to .05 . Data Screening was performed before the factorial analysis to evaluate the distribution of data and assumptions. The data screening consisted of the analysis of multivariate normality for the scales through the use of Mardia's Multivariate Normality Test, Additivity, Linearity, Homogeneity and Homoscedasticity. To analyze additivity, Pearson correlations between items were done. In order to examines the assumptions (Linearity, Homogeneity and Homoscedasticity), we analyze the residuals of the resulting regression between our results and a random dataset. Consequently, any irregularities would be due to our data.

Before the treatment of the data obtained with the scales, the validity and internal consistency of the scales were verified by Confirmatory Factor Analysis. Confirmatory Factorial Analysis (CFA) were conducted with the lavaan R package. Diagonally weighted least squares (DWLS) was used as estimation method for CFA to account for multivariate non-normality. Cronbach's alpha and McDonald $\omega$ were used to assess reliability (Revelle, 2019). The fit indices used in CFA and Mediation (and goodness of fit) were Comparative Fit Index (CFI; >.95 great; >.90 acceptable), TuckerLewis Index (TIF; >.90), Standardized Root Mean Square Residual (SRMS; >.09), and Root Mean Square Error of Approximation (RMSEA; >.05 good; 
$<.05-.10$ moderate) with 90\% of Confident interval. The semTools package was used to calculate the Composite Reliability (CR; >.7 great) and the Average Variance Extracted (AVE; >.5 great). Once the factorial treatment was done to the results of the scales, the scores given by the participants were scaled by the factor load resulting from the CFA. In other words, the raw scores given by the participants to each item were multiplied by the standardized factor loads of each item. A mediation analysis was conducted to analyze how resilience could mediate the relationship between the different personality factors and mental health. Due to the scaling of the variables used in the Mediation analysis, all the coefficients are estimated using Maximum Likelihood method implemented in the lavaan $\mathrm{R}$ package. The betas are obtained as standardized parameters of the path model. They are often called completely standardized effect size indexes. For the indirect effect, the beta is also called index of mediation.

\section{RESULTS}

Table 1 indicates the descriptive results obtained in each of the sub scales. Mardia's Multivariate Normality Test was performed to analyze multivariate normality for each of the subscales.

\section{Table 1}

Descriptives for items

\begin{tabular}{cccccccc}
\hline Scale & Items & $\mathbf{N}$ & $\boldsymbol{M}$ & $\boldsymbol{M} \boldsymbol{e}$ & $\boldsymbol{S D}$ & Skewness & Kurtosis \\
\hline Resilience & CP_1 & 692 & 5.57 & 6.00 & 1.02 & -.56 & .17 \\
\cline { 2 - 8 } & CP_2 & 692 & 6.18 & 6.00 & 1.05 & -1.58 & 3.04 \\
\cline { 2 - 8 } & CP_3 & 692 & 4.74 & 5.00 & 1.39 & -.39 & -.18 \\
\cline { 2 - 8 } & CP_4 & 692 & 4.84 & 5.00 & 1.42 & -.44 & -.21 \\
\cline { 2 - 8 } & CP_5 & 692 & 4.53 & 5.00 & 1.66 & -.26 & -.84 \\
\hline & CP_6 & 692 & 5.79 & 6.00 & 1.13 & -1.12 & 1.50 \\
\hline & CP_7 & 692 & 5.90 & 6.00 & 1.16 & -1.09 & 1.05 \\
\hline & CP_8 & 692 & 4.81 & 5.00 & 1.57 & -.55 & -.36 \\
\cline { 2 - 8 } & CP_9 & 692 & 6.36 & 7.00 & .91 & -1.83 & 4.29 \\
\cline { 2 - 8 } & CP_10 & 692 & 5.79 & 6.00 & 1.43 & -1.44 & 1.87 \\
\cline { 2 - 7 } & CP_11 & 692 & 5.42 & 6.00 & 1.15 & -.82 & .86 \\
\cline { 2 - 7 } & Ac_1 & 692 & 4.64 & 5.00 & 1.50 & -.26 & -.52 \\
\cline { 2 - 7 } & Ac_2 & 692 & 4.66 & 5.00 & 1.47 & -.58 & -.10 \\
\cline { 2 - 7 } & Ac_3 & 692 & 5.25 & 5.00 & 1.35 & -.75 & .37 \\
\hline
\end{tabular}




\begin{tabular}{|c|c|c|c|c|c|c|c|}
\hline Scale & Items & $\mathbf{N}$ & $M$ & $M e$ & $S D$ & Skewness & Kurtosis \\
\hline \multirow[t]{32}{*}{ Personality } & Ext_1 & 692 & 3.68 & 4.00 & 1.01 & -.48 & -.31 \\
\hline & Ext_2 & 692 & 3.58 & 4.00 & .98 & -.43 & -.03 \\
\hline & Ext_3 & 692 & 3.34 & 3.00 & 1.05 & -.15 & -.53 \\
\hline & Ext_4 & 692 & 3.40 & 3.00 & .93 & -.17 & -.24 \\
\hline & Ext_5 & 692 & 3.67 & 4.00 & .96 & -.47 & .02 \\
\hline & Ext_6 & 692 & 3.10 & 3.00 & 1.14 & -.01 & -.72 \\
\hline & Ext_7 & 692 & 3.13 & 3.00 & 1.19 & -.13 & -.81 \\
\hline & Ext_8 & 692 & 2.83 & 3.00 & 1.24 & .08 & -.92 \\
\hline & Agr_1 & 692 & 4.14 & 4.00 & .83 & -.73 & .33 \\
\hline & Agr_2 & 692 & 3.95 & 4.00 & .89 & -.64 & .11 \\
\hline & Agr_3 & 692 & 4.34 & 4.00 & .72 & -.83 & .34 \\
\hline & Agr_4 & 692 & 3.27 & 3.00 & 1.14 & -.21 & -.73 \\
\hline & Agr_5 & 692 & 3.50 & 4.00 & .97 & -.38 & -.21 \\
\hline & Agr_6 & 692 & 2.49 & 2.00 & 1.04 & .32 & -.60 \\
\hline & Agr_7 & 692 & 1.86 & 2.00 & 1.01 & 1.05 & .37 \\
\hline & Agr_8 & 692 & 2.65 & 3.00 & 1.17 & .25 & -.76 \\
\hline & Agr_9 & 692 & 1.79 & 1.00 & .98 & 1.17 & .76 \\
\hline & Esc_1 & 692 & 3.54 & 4.00 & .99 & -.27 & -.48 \\
\hline & Esc_2 & 692 & 3.77 & 4.00 & .81 & -.34 & .04 \\
\hline & Esc_3 & 692 & 3.38 & 3.00 & .97 & -.30 & -.34 \\
\hline & Esc_4 & 692 & 4.08 & 4.00 & .86 & -.71 & .12 \\
\hline & Esc_5 & 692 & 3.84 & 4.00 & .98 & -.47 & -.51 \\
\hline & Esc_6 & 692 & 3.35 & 3.00 & 1.05 & -.10 & -.54 \\
\hline & Esc_7 & 692 & 3.22 & 3.00 & 1.13 & -.17 & -.67 \\
\hline & Esc_8 & 692 & 2.38 & 2.00 & 1.17 & .52 & -.60 \\
\hline & Esc_9 & 692 & 2.63 & 3.00 & 1.29 & .25 & -1.03 \\
\hline & Neu_1 & 692 & 3.98 & 4.00 & .95 & -.67 & -.12 \\
\hline & Neu_2 & 692 & 2.75 & 3.00 & 1.08 & .21 & -.61 \\
\hline & Neu_3 & 692 & 3.21 & 3.00 & 1.13 & -.09 & -.73 \\
\hline & Neu_4 & 692 & 2.20 & 2.00 & 1.17 & .70 & -.50 \\
\hline & Neu_5 & 692 & 2.81 & 3.00 & 1.13 & .10 & -.71 \\
\hline & Neu_6 & 692 & 3.38 & 3.00 & .99 & -.22 & -.38 \\
\hline
\end{tabular}




\begin{tabular}{|c|c|c|c|c|c|c|c|}
\hline Scale & Items & $\mathbf{N}$ & M & $M e$ & $S D$ & Skewness & Kurtosis \\
\hline & Neu_7 & 692 & 2.98 & 3.00 & 1.08 & -.03 & -.61 \\
\hline & Neu_8 & 692 & 3.01 & 3.00 & 1.07 & -.01 & -.51 \\
\hline & Sin_1 & 692 & 3.11 & 3.00 & 1.09 & -.08 & -.56 \\
\hline & Sin $\_2$ & 692 & 3.52 & 4.00 & .96 & -.17 & -.55 \\
\hline & Sin_3 & 692 & 3.47 & 4.00 & 1.10 & -.31 & -.61 \\
\hline & Sin_4 & 692 & 3.61 & 4.00 & .99 & -.25 & -.68 \\
\hline & Sin $\_5$ & 692 & 3.68 & 4.00 & .94 & -.14 & -.75 \\
\hline & Sin_6 & 692 & 3.10 & 3.00 & 1.18 & -.04 & -.80 \\
\hline & Sin_7 & 692 & 3.38 & 3.00 & .89 & -.01 & -.26 \\
\hline & Sin_8 & 692 & 3.72 & 4.00 & .90 & -.25 & -.40 \\
\hline & Sin_9 & 692 & 2.98 & 3.00 & 1.11 & -.03 & -.56 \\
\hline & Sin_10 & 692 & 2.60 & 3.00 & 1.13 & .17 & -.75 \\
\hline \multirow{5}{*}{$\begin{array}{c}\text { Mental } \\
\text { Heals }\end{array}$} & mh_1 & 692 & 3.08 & 3.00 & 1.10 & -.11 & -.60 \\
\hline & mh_2 & 692 & 3.44 & 3.00 & 1.22 & -.29 & -.91 \\
\hline & mh_3 & 692 & 2.81 & 3.00 & 1.03 & .08 & -.62 \\
\hline & mh_4 & 692 & 3.32 & 3.00 & 1.18 & -.20 & -.87 \\
\hline & mh_5 & 692 & 2.58 & 2.00 & 1.22 & .37 & -.83 \\
\hline
\end{tabular}

The results showed that none of the data obtained for the three subscales reveal a normal multivariate distribution (Resilience Scale: $\mathrm{Z}_{\text {Kurtosis }}$ 42.988, $p<.01$; Personality Scale: $\mathrm{Z}_{\text {Kurtosis }}$ 35.492, $p<.01$; Mental Health Scale: $\left.\mathrm{Z}_{\text {Kurtosis }} 7.202, p<.01\right)$. Before the factorial treatment of the scales, we perform the data screening of the data from the different subscales to evaluate the assumptions necessary for its analysis. For additivity, we check the correlations between the items. No item showed multicollinearity $(r>.90)$, nor singularity $(r>.95)$. To evaluate the assumptions of linearity, homogeneity and homoscedasticity, a linear regression was generated with random numbers and scale scores. The distribution of the residues resulting from the regression was evaluated. If there is any anomaly in the distribution of the residuals, this would be due to the data obtained by the questionnaire, since the other variable was random data (Kline, 2015). The resulting distribution for each of the scales was not violating any assumptions, showing a distribution of standardized regression residuals mostly between -2 and +2 . 


\section{ANALYSIS OF THE SUBSCALES}

To confirm the validity and internal structure of the scales used, a Confirmatory Factor Analysis (CFA) was performed with the data obtained for each scale.

\section{Resilience Scale (RS-14)}

Standardized factor loads for this scale varied between.739 (SE .033) and.381 (SE .021), for more details see Table 2. The CFA for RS-14 scale indicates an excellent fit (Hair et al., 2010), $x^{2}(76)=204.763, p<.001$, with $\mathrm{CFI}=.973$, TLI $=.968$, SRMR $=.067$, RMSEA $=.050$ (RMSEA 90\% CI $[.041, .058])$. The reliability of this scale was Cronbach's $\alpha=.841$ and McDonald's $\omega=.848$ for Personal Competence, and Cronbach's $\alpha=.543$ and McDonald's $\omega=.612$ for Acceptance (Cronbach's $\alpha=.867$ and McDonald's $\omega$ $=.872$ for the total scale).

\section{PERSONALITY SCALE (BIG FIVE)}

Standardized factor loads for this scale varied between.787 (SE 0.023) and.348 (SE 0.020), for more details see Table 2.

\section{Table 2}

Factor loading

\begin{tabular}{|c|c|c|c|c|c|c|c|c|c|}
\hline Scale & $\begin{array}{l}\text { Latent } \\
\text { Factor } \\
\end{array}$ & Indicator & Estimate & SE & $Z$ & $p$ & $\begin{array}{c}\text { Stand. } \\
\text { Estimate }\end{array}$ & $C R$ & $A V E$ \\
\hline \multirow{14}{*}{ 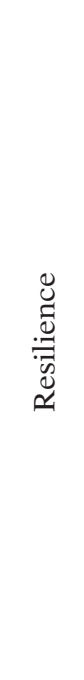 } & \multirow{11}{*}{$\begin{array}{l}\text { Personal } \\
\text { Competence }\end{array}$} & pc_1 & .606 & .023 & 26.255 & $<.001$ & .593 & \multirow[t]{11}{*}{.846} & \multirow[t]{11}{*}{.357} \\
\hline & & pc_2 & .516 & .026 & 19.592 & $<.001$ & .490 & & \\
\hline & & pc_3 & 1.028 & .033 & 31.327 & $<.001$ & .739 & & \\
\hline & & pc_4 & 1.027 & .033 & 31.523 & $<.001$ & .725 & & \\
\hline & & pc_5 & .810 & .034 & 23.581 & $<.001$ & .487 & & \\
\hline & & pc_6 & .513 & .025 & 2.830 & $<.001$ & .456 & & \\
\hline & & pc_7 & .554 & .027 & 2.502 & $<.001$ & .477 & & \\
\hline & & pc_8 & 1.094 & .036 & 3.263 & $<.001$ & .695 & & \\
\hline & & pc_9 & .345 & .021 & 16.842 & $<.001$ & .381 & & \\
\hline & & pc_10 & .714 & .033 & 21.730 & $<.001$ & .498 & & \\
\hline & & pc_11 & .829 & .028 & 29.338 & $<.001$ & .720 & & \\
\hline & \multirow{3}{*}{ Acceptance } & ac_1 & .594 & .037 & 16.147 & $<.001$ & .396 & \multirow[t]{3}{*}{.557} & \multirow[t]{3}{*}{.306} \\
\hline & & ac_2 & 1.033 & .054 & 19.169 & $<.001$ & .701 & & \\
\hline & & ac_3 & .705 & .039 & 17.942 & $<.001$ & .521 & & \\
\hline
\end{tabular}




\begin{tabular}{|c|c|c|c|c|c|c|c|c|c|}
\hline Scale & $\begin{array}{l}\text { Latent } \\
\text { Factor } \\
\end{array}$ & Indicator & Estimate & SE & $Z$ & $p$ & $\begin{array}{c}\text { Stand. } \\
\text { Estimate }\end{array}$ & $C R$ & $A V E$ \\
\hline \multirow{33}{*}{ 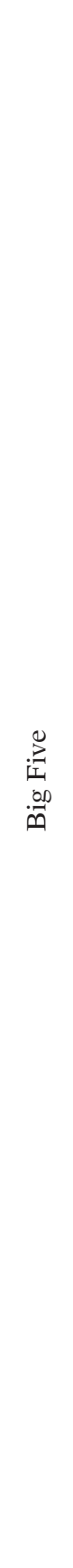 } & \multirow[t]{5}{*}{ Extraversion } & ext_1 & .217 & .040 & 5.391 & $<.001$ & .518 & \multirow[t]{5}{*}{.664} & \multirow[t]{5}{*}{.293} \\
\hline & & ext_2 & .162 & .030 & 5.319 & $<.001$ & .398 & & \\
\hline & & ext_3 & .177 & .033 & 5.394 & $<.001$ & .407 & & \\
\hline & & ext_4 & .263 & .048 & 5.442 & $<.001$ & .682 & & \\
\hline & & ext_5 & .254 & .047 & 5.444 & $<.001$ & .640 & & \\
\hline & \multirow[t]{5}{*}{$\begin{array}{l}\text { Agreeable- } \\
\text { ness }\end{array}$} & agr_1 & .269 & .033 & 8.166 & $<.001$ & .632 & \multirow[t]{5}{*}{.641} & \multirow[t]{5}{*}{.274} \\
\hline & & agr_2 & .279 & .034 & 8.187 & $<.001$ & .612 & & \\
\hline & & agr_3 & .195 & .025 & 7.884 & $<.001$ & .527 & & \\
\hline & & agr_5 & .236 & .030 & 7.956 & $<.001$ & .475 & & \\
\hline & & agr_8 & .180 & .024 & 7.610 & $<.001$ & .301 & & \\
\hline & \multirow[t]{5}{*}{$\begin{array}{l}\text { Conscien- } \\
\text { tiousness }\end{array}$} & con_1 & .302 & .020 & 15.442 & $<.001$ & .410 & \multirow[t]{6}{*}{.714} & \multirow[t]{6}{*}{.308} \\
\hline & & con_2 & .373 & .020 & 18.901 & $<.001$ & .620 & & \\
\hline & & con_3 & .328 & .020 & 16.331 & $<.001$ & .455 & & \\
\hline & & con_4 & .440 & .023 & 19.098 & $<.001$ & .684 & & \\
\hline & & con_5 & .517 & .027 & 19.388 & $<.001$ & .709 & & \\
\hline & \multirow{8}{*}{ Neuroticism } & con_8 & .298 & .022 & 13.582 & $<.001$ & .343 & & \\
\hline & & neu_2 & .424 & .030 & 14.137 & $<.001$ & .416 & \multirow[t]{7}{*}{.765} & \multirow[t]{7}{*}{.325} \\
\hline & & neu_3 & .445 & .029 & 15.306 & $<.001$ & .419 & & \\
\hline & & neu_4 & .710 & .041 & 17.500 & $<.001$ & .646 & & \\
\hline & & neu_5 & .565 & .034 & 16.741 & $<.001$ & .530 & & \\
\hline & & neu_6 & .632 & .034 & 18.333 & $<.001$ & .679 & & \\
\hline & & neu_7 & .587 & .029 & 2.155 & $<.001$ & .577 & & \\
\hline & & neu_8 & .665 & .034 & 19.719 & $<.001$ & .659 & & \\
\hline & \multirow[t]{8}{*}{ Openness } & ope_1 & .522 & .021 & 24.730 & $<.001$ & .611 & \multirow[t]{8}{*}{.803} & \multirow[t]{8}{*}{.349} \\
\hline & & ope_2 & .531 & .020 & 27.166 & $<.001$ & .707 & & \\
\hline & & ope_3 & .368 & .019 & 18.913 & $<.001$ & .426 & & \\
\hline & & ope_4 & .613 & .023 & 26.572 & $<.001$ & .787 & & \\
\hline & & ope_5 & .469 & .018 & 25.416 & $<.001$ & .638 & & \\
\hline & & ope_6 & .320 & .020 & 15.922 & $<.001$ & .348 & & \\
\hline & & ope_7 & .401 & .017 & 23.441 & $<.001$ & .572 & & \\
\hline & & ope_8 & .366 & .018 & 2.071 & $<.001$ & .516 & & \\
\hline & \multirow[t]{2}{*}{ Personality } & $\begin{array}{l}\text { Extraver- } \\
\text { sion }\end{array}$ & 2.203 & .433 & 5.088 & $<.001$ & .911 & & \\
\hline & & $\begin{array}{l}\text { Agreeable- } \\
\text { ness }\end{array}$ & 1.672 & .223 & 7.490 & $<.001$ & .858 & & \\
\hline
\end{tabular}




\begin{tabular}{|c|c|c|c|c|c|c|c|c|c|}
\hline Scale & $\begin{array}{l}\text { Latent } \\
\text { Factor }\end{array}$ & Indicator & Estimate & SE & $Z$ & $p$ & $\begin{array}{c}\text { Stand. } \\
\text { Estimate }\end{array}$ & $C R$ & $A V E$ \\
\hline & & $\begin{array}{l}\text { Conscien- } \\
\text { tiousness }\end{array}$ & .898 & .051 & 17.578 & $<.001$ & .668 & & \\
\hline & & $\begin{array}{l}\text { Neuroti- } \\
\text { cism }\end{array}$ & -.361 & .018 & -2.464 & $<.001$ & -.339 & & \\
\hline & & Openness & .791 & .034 & 23.433 & $<.001$ & .620 & & \\
\hline \multirow{5}{*}{ 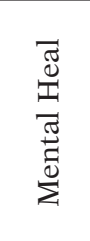 } & \multirow[t]{5}{*}{ MH } & mh_1 & .573 & .032 & 17.675 & $<.001$ & .519 & .803 & .457 \\
\hline & & $\mathrm{mh} \_2$ & .957 & .042 & 22.985 & $<.001$ & .785 & & \\
\hline & & mh_3 & .634 & .032 & 2.132 & $<.001$ & .619 & & \\
\hline & & mh_4 & .974 & .042 & 23.284 & $<.001$ & .823 & & \\
\hline & & mh_5 & .711 & .036 & 19.766 & $<.001$ & .584 & & \\
\hline
\end{tabular}

The CFA for the original Big Five scale showed a poor fit, $\chi^{2}(735)=$ 4586.37, $p<.001$, with CFI $=.735$, TLI $=.718$, SRMR $=.095$, RMSEA $=.087$ (RMSEA 90\% CI [.085,.090]). An analysis of the results obtained with the original model showed that some items had a very low factor load (below .30) in the model. Analysis of the resulting CFA estimation errors showed that the Modification Index (MI) of these items was greater than $10.83(\alpha=$ 0.001). This led us to remove these items from the analysis, (Ext_6, Ext_7, Ext_8, Agr_4. Agr_6, Agr_7, Agr_9, Esc_6, Esc_7, Esc_9, Neu_1, Sin_9, Sin_10) and the CFA was performed with the resulting model. The CFA for reduced scale indicates a good fit (Hair et al., 2010), $\chi^{2}(420)=1383.67$, $p<.001$, with CFI $=.908$, TLI $=.899$, SRMR $=.068$, RMSEA $=.058$ (RMSEA $90 \%$ CI $[.054, .061]$ ). The results of comparing both models (original vs. reduced) showed that the model of the reduced version of the Big Five was significantly better adjusted than the model of the original version, $\chi^{2}$ (315) $=3202.7, p<.001$. The reliability of the total reduced scale was Cronbach's $\alpha=.762$ and McDonald's $\omega=.796$ (Extraversion: Cronbach's $\alpha=.679$ and McDonald's $\omega=.689$; Agreeableness: Cronbach's $\alpha=.589$ and McDonald's $\omega=.637$; Conscientiousness: Cronbach's $\alpha=.702$ and McDonald's $\omega=.718$; Neuroticism: Cronbach's $\alpha=.758$ and McDonald's $\omega=.716$; Openness: Cronbach's $\alpha=.799$ and McDonald's $\omega=.806$ ).

\section{Mental Health Scale}

Standardized factor loads for this scale varied between.823 (SE .042) and.519 (SE .032), for more details see Table 2. The CFA for Mental Health scale displays an excellent fit (Hair et al., 2010), $\chi^{2}(5)=44.843, p<.001$, with CFI $=.970$, TLI $=.941$, SRMR $=.069$, RMSEA $=.107$ (RMSEA 90\% CI $[.080, .137])$. The reliability of this scale was Cronbach's $\alpha=.798$ and McDonald's $\omega=.804$. 


\section{MEDIATION ANALYSIS}

\section{Figure 1}

Mediational model of personality factors $($ Agr = Agreeableness; Ext $=$ Extraversion; Cons $=$ Conscientiousness; $N e u=$ Neuroticism; Ope= Openness), Resilience (RES) and Mental Health $(M H)$. The rectangular figures represent the scaled values of the factors. The arrows indicate the regression relationships. Continuous arrows indicate significant relationships and non-significant discontinuous arrows

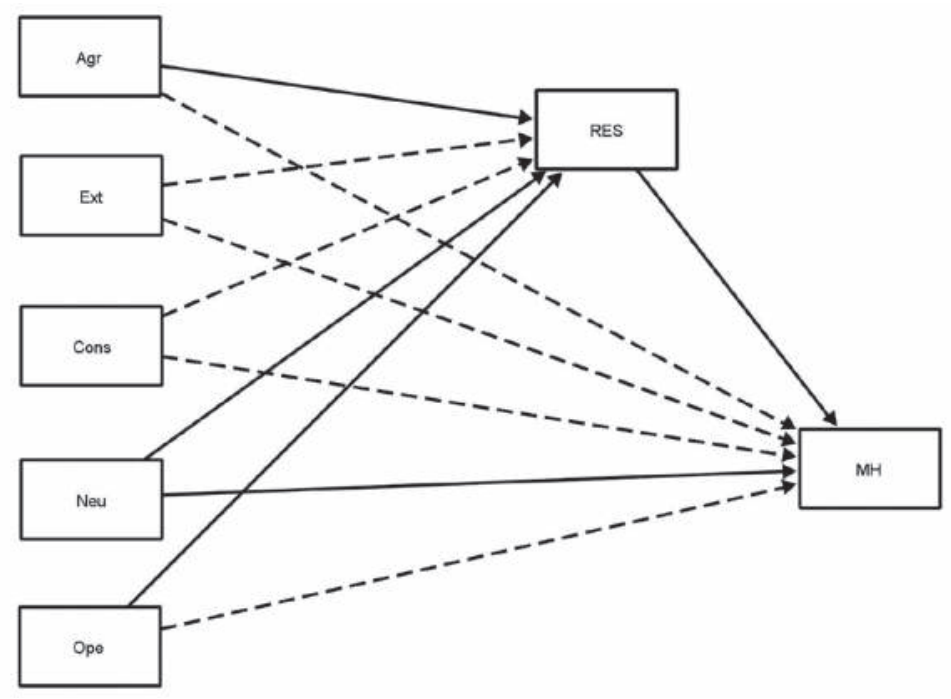

With the aim of analyzing how the mediating role of resilience could affect the relation between personality factors and mental health, a mediational analysis was proposed. Figure 1 represents the relationships proposed in the mediation model. The rectangular figures represent the scaled values of the latent variables, and the arrows indicate the direction of the proposed relationship between the variables. Those relationships that were significant are marked with black arrows and the non-significant ones with discontinuous arrows. The results of the analyzed mediational model showed a good fit, $\chi^{2}(10)=31.05, p<.001$, with CFI $=.920$, TLI $=.824$, SRMR $=.044$, RMSEA $=.087$ (RMSEA 90\% CI [.059,.117]). Table 3 displays the direct and indirect results of the mediational analysis. These results evaluate the mediating role that resilience plays between personality components and mental health. These results reveal that the unique personality factor that significantly and directly predicts students' Mental Health (MH) is Neuroticism (Neu), as expected, this relationship is inverse $(\beta=-.306)$. Except for Extraversion (Ext) and Conscientiousness (Cons), all personality factors were shown to be significantly related to Resilience (RES), but more importantly, RES was 
shown to be a significant mediator between the relationship of Agr, Neu and Ope personality components and Mental Health.

Table 3

Indirect and total effect from mediation analysis

95\% C.I. (a)

\begin{tabular}{|c|c|c|c|c|c|c|c|c|}
\hline Type & Effect & Estimate & SE & Lower & Upper & $\beta$ & $z$ & $p$ \\
\hline \multirow{5}{*}{ 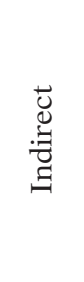 } & $\mathrm{Ext} \Rightarrow \mathrm{RES} \Rightarrow \mathrm{MH}$ & .007 & .010 & -.012 & .026 & .004 & .733 & .463 \\
\hline & $\mathrm{Agr} \Rightarrow \mathrm{RES} \Rightarrow \mathrm{MH}$ & .024 & .012 & .002 & .048 & .011 & 2.032 & .042 \\
\hline & Cons $\Rightarrow$ RES $\Rightarrow \mathrm{MH}$ & .016 & .012 & -.008 & .040 & .008 & 1.286 & .198 \\
\hline & $\mathrm{Neu} \Rightarrow \mathrm{RES} \Rightarrow \mathrm{MH}$ & -.114 & .035 & -.183 & -.047 & -.074 & -3.285 & .001 \\
\hline & Ope $\Rightarrow$ RES $\Rightarrow \mathrm{MH}$ & .065 & .023 & .021 & .111 & .036 & 2.829 & .005 \\
\hline \multirow{6}{*}{$\begin{array}{l}\overrightarrow{0} \\
\ddot{0} \\
0 \\
\tilde{\Xi} \\
0 \\
0\end{array}$} & Ext $\Rightarrow$ RES & .040 & .053 & -.063 & .143 & .027 & .753 & .451 \\
\hline & $\mathrm{RES} \Rightarrow \mathrm{MH}$ & .179 & .053 & .078 & .285 & .149 & 3.386 & $<.001$ \\
\hline & Agr $\Rightarrow$ RES & .133 & .054 & .030 & .243 & .077 & 2.449 & .014 \\
\hline & Cons $\Rightarrow$ RES & .087 & .060 & -.030 & .207 & .054 & 1.439 & .150 \\
\hline & $\mathrm{Neu} \Rightarrow$ RES & -.636 & .043 & -.721 & -.551 & -.498 & -14.706 & $<.001$ \\
\hline & Ope $\Rightarrow$ RES & .364 & .060 & .247 & .481 & .241 & 6.088 & $<.001$ \\
\hline \multirow{5}{*}{$\begin{array}{l}\vec{U} \\
\stackrel{D}{0} \\
\vec{\theta}\end{array}$} & $\mathrm{Ext} \Rightarrow \mathrm{MH}$ & -.051 & .063 & -.173 & .076 & -.030 & -.813 & .416 \\
\hline & $\mathrm{Agr} \Rightarrow \mathrm{MH}$ & -.098 & .077 & -.256 & .046 & -.047 & -1.274 & .203 \\
\hline & Cons $\Rightarrow \mathrm{MH}$ & .083 & .078 & -.074 & .233 & .043 & 1.065 & .287 \\
\hline & $\mathrm{Neu} \Rightarrow \mathrm{MH}$ & -.469 & .064 & -.591 & -.341 & -.306 & -7.344 & $<.001$ \\
\hline & Ope $\Rightarrow \mathrm{MH}$ & .023 & .075 & -.124 & .171 & .012 & .299 & .765 \\
\hline \multirow{5}{*}{ 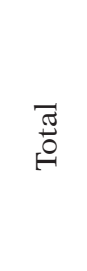 } & Ext $\Rightarrow \mathrm{MH}$ & -.044 & .065 & -.172 & .083 & -.026 & -.683 & .495 \\
\hline & $\mathrm{Agr} \Rightarrow \mathrm{MH}$ & -.074 & .079 & -.230 & .081 & -.036 & -.939 & .348 \\
\hline & Cons $\Rightarrow \mathrm{MH}$ & .099 & .078 & -.053 & .251 & .051 & 1.273 & .203 \\
\hline & $\mathrm{Neu} \Rightarrow \mathrm{MH}$ & -.583 & .055 & -.690 & -.476 & -.380 & -1.638 & $<.001$ \\
\hline & Ope $\Rightarrow \mathrm{MH}$ & .088 & .074 & -.057 & .232 & .048 & 1.193 & .233 \\
\hline
\end{tabular}

Notes. RES $=$ resilience, $\mathrm{MH}=$ Mental health $;$ Ext $=$ Extraversion, Agr $=$ Agreeableness, Cons $=$ Conscientiousness, $\mathrm{Neu}=$ Neuroticism, Ope $=$ Openness. (a) Confidence intervals computed with method: Parametric bootstrap.

Finally, table 4 indicates the Pearson correlation analysis for the variables that were involved in the mediation model. 
Table 4

Pearson Correlation Matrix

\begin{tabular}{|c|c|c|c|c|c|c|c|c|c|c|c|c|c|}
\hline & Ext & & Agr & & Cons & & Neu & & Ope & & RES & & MH \\
\hline Ext & - & & & & & & & & & & & & \\
\hline Agr & .137 & $* * *$ & - & & & & & & & & & & \\
\hline Cons & .321 & $* * *$ & .273 & $* * *$ & - & & & & & & & & \\
\hline Neu & -.008 & & .138 & $* * *$ & .101 & $* *$ & - & & & & & & \\
\hline Ope & .279 & $* * *$ & .345 & $* * *$ & .409 & $* * *$ & -.039 & & - & & & & \\
\hline RES & .127 & $* * *$ & .110 & $* *$ & .132 & $* * *$ & -.491 & $* * *$ & .317 & $* * *$ & - & & \\
\hline $\mathrm{MH}$ & .002 & & -.061 & & .015 & & -.382 & $* * *$ & .065 & & .300 & $* * *$ & - \\
\hline
\end{tabular}

Note . RES $=$ resilience, $\mathrm{MH}=$ Mental health; Ext $=$ Extraversion, Agr $=$ Agreeableness, Cons $=$ Conscientiousness, Neu $=$ Neuroticism, Ope $=$ Openness $* \mathrm{p}<.05, * * \mathrm{p}<.01, * * * \mathrm{p}<.001$

\section{DISCUSSION AND CONCLUSIONS}

Due to the absence of studies that examined resilience, personality and mental health variables in pre-service teachers as a whole, the purpose of the study was to test the mediating role of pre-service teachers' resilience with respect to their mental health and personality factors, through structural equation modeling. This research arose because the role of personality and resilience for determining health and well-being are concepts of both theoretical and practical importance (Robertson et al., 2018). As noted by $\mathrm{Lu}$ et al. (2014), resilience may play an important role as a mediator between personality traits and psychological well-being. The analysis showed that resilience partially mediated the relationship between three personality factors and mental health, with agreeableness and openness positively, and neuroticism negatively, affecting mental health through resilience. Subjects with modesty and sympathy towards others; and with active imagination and sensitivity to emotional reactions show a positive relationship with resilience; on the other hand, subjects who are sensitive to distress and who feel vulnerable to pressure and stress are negatively related to resilience. We also found that the only personality factor that also directly influences mental health was neuroticism negatively. Several studies have shown that neuroticism is a risk factor for developing depressive symptoms, if we consider that mental health was measured taking into account the anxiety and depressive symptomatology of the subjects using the MH-5. Our results are consistent with other studies that have shown that neuroticism plays a key role in predicting depressive symptomatology (Gong et al., 2020).

On the other hand, resilience played a mediating role in the relationship between personality traits and mental health, i.e. personality traits could indirectly affect mental health by influencing resilience. If we 
assume what Connor and Davidson (2003) state about resilient individuals and their ability for adaptation to success, resilient people are those who are able to adapt to adversity while maintaining their psychological health. According to the study developed by Vinciguerra et al. (2019), who analyzed the relationship between personality and academic performance, they found that students who were more resilient were less likely to have mental problems. In relation to personality, they found a strong link between the neuroticism component and mental health. These results are consistent with the findings of this research. Other studies such as that conducted by Zhang et al. (2018) have also examined the relationship between resilience and psychological distress in Chinese university students. From a gender perspective, they found that women are more likely to have psychological distress than men. Similarly, research has indicated that among the factors that undermine mental health, stress, psychological distress, anxiety and self-esteem rank as the most common (Oshio et al., 2018). Resilience is a dynamic process in which people mobilize available resources to recover from adversity and personality traits tend to predispose people to proactively cope with adverse events with a positive appraisal style and, subsequently, to develop resilience.

These findings are common to studies such as the meta-analysis developed by Oshio et al. (2018), in which from personality as a trait perspective, they affirm that there are some characteristics and abilities within individuals that contribute to overcoming life's obstacles and preventing mental problems. This conception of resilience addresses what Gu and Day (2007) call "protection processes", where the combination of teachers' personal qualities and contextual factors act as predictors of the effectiveness and management of teachers in their professional performance.

Within the framework of the need to train pre-service teachers in psychosocial factors, the research carried out by Le Cornu (2009) is contextualized in the practicum. Among his findings, he highlights that training in resilience acts as "reinforcement" to face the challenges of the teaching profession and ensure professional satisfaction, especially in the first years, noting the importance of resilience in order to address mental health problems, which coincides with our results. In this regard, resilience training is carried out by highlighting the importance of pre-service teachers' relationships and their complex exchanges with their pupils and the context in which they work. In short, this study establishes the basis to proliferate research lines required to develop training strategies capable of preventing and providing skills to pre-service teachers about psychosocial factors which impact their mental health (Shackleton et al., 2019). Future research will try to explore in depth the relationship of the constructs analyzed with other 
psychosocial variables, in order to provide a profile of a "good teacher" and to implement training programs that will ensure this end.

Finally, this study has a set of limitations that should be considered. The first of these concerns the sample. Consistent with the distribution of the population in education degrees in Spain, a supremacy of women over men has been found. This fact means that the analyses by gender should be treated with caution. Furthermore, there are also limitations related to the research design itself. It has a cross-sectional design, so it does not allow us to establish any causal effects between the study variables. Future research on this subject should consider and evaluate moderation models using a longitudinal design.

\section{DECLARATIONS}

- Informed consent was obtained from all individual participants included in the study. The datasets generated during and/or analyzed during the current study are available from the corresponding author on reasonable request. The authors did not receive support from any organization for the submitted work.

- Acknowledgements: The research is included within the IberoAmerican Network for the Development of Professional Teaching Identity. 


\section{REFERENCES}

Aguaded Gómez, $\mathbf{M}^{\mathrm{a}} \mathrm{C}$., \& Almeida Pires Cavaco, N. A. (2016). La resiliencia del docente como factor crucial para superar las adversidades en una sociedad de cambios. Tendencias Pedagógicas, 28, 167-179. https://doi. org/10.15366/tp2016.28.012

Alonso, J., Prieto, L., \& Anto, JM. (1995). La versión española del SF-36 Health Survey (Cuestionario de Salud SF-36): un instrumento para la medida de los resultados clínicos. Medicina Clínica, 104(20), 771-776.

Alonso-Fernández, F. (2014). Una panorámica de la salud mental de los profesores. Revista Iberoamericana de Educación, 66, 19-30. https://doi. org/10.35362/rie660375

Anderson, M., Werner-Seidler, A., King, C., Gayed, A., Harvey, S. B., \& O’Dea, B. (2019). Mental health training programs for secondary school teachers: a systematic review. School Mental Health, 11(3), 489-508. https:// doi.org/10.1007/s12310-018-9291-2

Auerbach R. P., Alonso J., Axinn W.G., Cuijpers P., Ebert D. D., \& Green J. G. (2016). Mental disorders among college students in the World Health Organization World Mental Health Surveys. Psychol Med., 46(14), 2955-70. https://doi.org/10.1017/ S0033291716001665

Ballester, L., Alayo, I., Vilagut, G., Almenara, J., Cebrià, A. I., Echeburúa, E.,.. \& Jordi, A. (2020). Mental disorders in Spanish university students: Prevalence, age-of-onset, severe role impairment and mental health treatment. Journal of Affective Disorders, 273, 604-613. https://doi. org/10.1016/j.jad.2020.04.050
Belykh, A. (2018). Resiliencia e inteligencia emocional: conceptos complementarios para empoderar al estudiante. Revista Latinoamericana de Estudios Educativos, 48(1), 255-282. https://doi.org/10.48102/ rlee.2018.48.1.81

Benet-Martínez, V., \& Johnson, O. P. (1998). Los Cinco Grandes across cultures and ethnic groups: Multitrait multimethod analyses of the Big Five in Spanish and English. Journal of Personality and Social Psychology, 75(3), 729-750. http://doi. org/10.1037/0022-3514.75.3.729

Bore, M., Pittolo, C., Kirby, D., Dluzewska, T., \& Marlin, S. (2016). Predictors of psychological distress and well-being in a sample of Australian undergraduate students. Higher Education Research \& Development, 35(5), 869-880. https:// doi.org/10.1080/07294360.2016.1138 452

Carmel, R., \& Badash, M. (2019). Who is the effective teacher? Perceptions of early career English teachers in Israel. The Language Learning Journal, 49(5), 1-16. https://doi.org/10.1080/09571736 .2019 .1656767

Conley, C.S., Durlak, J.A., \& Kirsch, A.C. (2015). A meta-analysis of universal mental health prevention programs for higher education students. Prevention Science, 16, 487-507. https://doi. org/10.1007/s11121-015-0543-1

Connor, K. M., \& Davidson, J. R. T. (2003). Development of a new resilience scale: The Connor-Davidson Resilience Scales (CD-RISC). Depression and Anxiety, 18(2), 76-82. https://doi.org/10.1002/da.10113 
Costa, P. T., \& McCrae, R. R. (1985). The NEO Personality Inventory manual. Psychological Assessment Resources.

Costa, P. T., \& McCrae, R. R. (1992). The five-factor model of personality and its relevance to personality disorders. Journal of Personality Disorders, 6(4), 343-359. https://doi.org/10.1521/ pedi.1992.6.4.343

Digman, J. M. (1990). Personality structure: Emergence of the five-factor model. Annual Review of Psychology, 41, 417-440. http://dx.doi.org/10.1146/ annurev.ps.41.020190.002221

Fitchett, P. G., McCarthy, C. J., Lambert, R. G., \& Boyle, L. (2018). An examination of US first-year teachers' risk for occupational stress: associations with professional preparation and occupational health. Teachers and Teaching, 24(2), 99-118. https://doi.org/10.1080/13540602.2017 .1386648

Gong, Y., Sji, J., Ding, H., Zhang, M., Kang, Ch., Wang, K., Yu, Y., Wei, J., Wang, S., Shao, N., \& Han, J. (2020). Personality traits and depressive symptoms: the moderating and mediating effects of resilience in Chinese adolescents. Journal of Affective Disorders, 265, 611-617. https://doi.org/10.1016/j. jad.2019.11.102

Irie, T., Yokomitsu, K., \& Sakano, Y. (2019). Relationship between cognitive behavioral varialbes and mental health status among university students: A meta-analysis. PLoS One, 14(9), e0223310. https://doi.org/10.1371/ journal.pone.0223310

John, O. P., Naumann, L-P., \& Soto, C.J. (2008). Paradigm shift to the integrative big-five trait taxonomy: Histori, measurement, and coceptual issues. In O.P. John, R.W. Robins, \& A.
Pervin (Eds.), Handbook of personality: Theory and research (pp. 114-158). Guilford Press.

John, O. P., \& Srivastava, S. (1999). The big five trait taxonomy: History, measurement, and theoretical perspectives. In L. A. Pervin \& O. P. John (Eds.), Handbook of Personality: Theory and Research (2nd ed., pp. 102139). Guilford Press.

Kelley, T., Kessel, A., Collings, R., Rubenstein, B., Monnickendam, C., \& Solomon, A. (2021). Evaluation of the iHEART mental health education programme on resilience and wellbeing of UK secondary school adolescents. Journal of Public Mental Health, 20(1), 43-50. https://doi. org/10.1108/JPMH-03-2020-0019

Le Cornu, R. (2009). Building resilience in pre-service teachers. Teaching and Teacher Education, 25(5), 717-723. https://doi.org/10.1016/j. tate.2008.11.016

Leon, M. R., \& Halbesleben, J. R. B. (2014). Building resilience to improve employee wellbeing. In A. M. Rossi, J. A. Meurs, \& P. L. Perrewe (Eds.), Improving employee health and wellbeing (pp. 65). Information Age Publishing.

Li, Z. S., \& Hasson, F. (2020). Resilience, stress, and psychological well-being in nursing students: A systematic review. Nurse Education Today, 90, 104440. https://doi.org/10.1016/j. nedt.2020.104440

Liu, M., \& Yan, Y. (2020). Anxiety and stress in in-service Chinese university teachers of Arts. International journal of higher education, 9(1), 237-248. https://doi.org/10.5430/ijhe.v9n1p237

Lu, W., Wang, Z., Liu, Y., \& Zhang, H. (2014). Resilience as a mediator between extraversion, neuroticism 
and happiness, PA and NA. Personality and Individual Differences, 63, 128- 133. https://doi.org/10.1016/j. paid.2014.01.015

Lyubomirsky, S., Sheldon, K. M., \& Schkade, D. (2005). Pursuing happiness: The architecture of sustainable change. Review of General Psychology, 9(2), 111-131. https://doi. org/10.1037/1089-2680.9.2.111

McCrae, R. R., \& Costa, P. T., Jr. (2008). The five-factor theory of personality. In O. P. John, R. W. Robins, \& L. A. Pervin (Eds.), Handbook of personality: Theory and research (p. 159-181). Guilford Press.

Mérida-López, S., Extremera, N., Quintana-Orts, C., \& Rey, L. (2020). Sentir ilusión por el trabajo docente: inteligencia emocional y el papel del afrontamiento resiliente en un estudio con profesorado de secundaria. Revista de Psicología y Educación, 15(1), 67-76. https://doi.org/10.23923/ rpye 2020.01 .186

Oshio, A., Taku, K., Hirano, M., \& Saeed, G. (2018). Resilience and Big Five personality traits: A meta-analysis. Personality and Individual Differences, 127, 54-60. https://doi.org/10.1016/j. paid.2018.01.048

Ramón-Arbués, E., Gea-Caballero, V., Granada-López, J. M., Juárez-Vela, R., Pellicer-García, B., \& AntónSolanas, I. (2020). The prevalence of depression, anxiety and stress and their associated factors in college students. International Journal of Environmental Research and Public Health, 17(19), 7001. https://doi. org/10.3390/ijerph17197001

Revelle, W. (2019). psych: procedures for psychological, psychometric, and personality research. [ $\mathrm{R}$ package].
Retrieved from https:/cran.r-project. org/package $=$ psych

Richardson M., Abraham C., \& Bond, R. (2012). Psychological correlates of university students' academic performance: A systematic review and meta-analysis. Psychology Bulletin, 138(2), 353-87. https://doi.org/10.1037/ a0026838

Robertson, I., Leach, D., \& Dawson, J. (2018). 'Personality and resilience: Domains, facets, and non-linear relationships'. International Journal of Stress Prevention and Wellbeing, 2(3), 1-10.

Sánchez-Teruel, D., \& Robles-Bello, M. A. (2015). Escala de esiliencia 14 ítems (RS-14): Propiedades psicométricas de la versión en español [14-item Resilience Scale (RS)-14): Psychometric properties of the Spanish version]. Revista Iberoamericana de Diagnóstico y Evaluación Psicologica, 40(2), 103-113.

Sautelle, E., Bowles, T., Hattie, J., \& Arifin, D. N. (2015). Personality, resilience, self-regulation and cognitive ability relevant to teacher selection. Australian Journal of Teacher Education, 40(4), 54-71. http://dx.doi. org/10.14221/ajte.2015v40n4.4

Shackleton, N., Bonell, C., Jamal, F., Allen, E., Mathiot, A., Elbourne, D., \& Viner, R. (2019). Teacher burnout and contextual and compositional elements of school environment. Journal of school health, 89(12), 977993. https://doi.org/10.1111/josh.12839

Steptoe A., Hamer M., \& Chida Y. (2007). The effects of acute psychological stress on circulating inflammatory factors in humans: a review and metaanalysis. Brain Behav. Immun, 21(7), 901-912. https://doi.org/10.1016/j. bbi.2007.03.011 
Vinciguerra, A., Réveillère, C., Potard, C., Lyant, B., Cornu, L., \& Courtois, R. (2019). Personality profiles of students at risk of dropping out: Resilients, Overcontrollers and Undercontrollers. L'Encephale, 45(2), 152-161. https://doi.org/10.1016/j. encep.2018.07.002
Zhang, M., Zhang, J., Zhang, F., Zhang, L., \& Feng, D. (2018). Prevalence of psychological distress and the effects of resilience and perceived social support among Chinese college students: Does gender make a difference? Psychiatry research, 267, 409-413. https://doi. org/10.1016/j.psychres.2018.06.038 


\section{ANALYSIS OF THE PSYCHOSOCIAL PROFILE OF PRE-SERVICE TEACHERS}

Inmaculada García-Martínez. ORCID: https:/orcid.org/0000-0003-2620-577

Assistant Lecturer at department of Didactics and School Organization in University of Granada (Spain). She is currently working about teachers' professional identity, educational technology, psychosocial factors of university students and their professional development.. E-mail: igmartinez@ugr.es

José María Augusto-Landa. ORCID: https://orcid.org/0000-0003-0350-3837

Tenured lecturer in the Department of Psychology at the University of Jaén. His lines of research focus on the construct of Emotional Intelligence and its applications in health and education fields. E-mail: jaugusto@ujaen.es

Eufrasio Pérez-Navío. ORCID: https://orcid.org/0000-0001-8688-9602

Tenured lecturer at the University of Jaén. His research lines focus on educational technology, university students and teachers' professional identity. E-mail: epnavio@ujaen.es

Samuel P. León. ORCID: https://orcid.org/0000-0002-6980-2680

Samuel P. León is Assistant Lecturer in the Department of Education at the University of Jaén. He has a PhD in Psychology. His research interest focuses on the research methodology of human sciences and behavioral sciences. Researcher and advocate of Evidence-Based Education. E-mail: sparra@ujaen.es

Fecha Recepción del Artículo: 09. Marzo. 2021

Fecha Modificación del Artículo: 02. Junio. 2021

Fecha Aceptación del Artículo: 12. Julio. 2021

Fecha Revisión para Publicación: 13. Septiembre. 2021 